\title{
Sifat Kimia dan Organoleptik Permen Jelly Buah Naga (Hylocereus Polyrhizus) dengan Penambahan Karagenan sebagai Gelling Agent
}

\author{
Chemical Properties and Organoleptic of Dragon Fruit Jelly Candy (Hylocereus \\ Polyrhizus) with the Addition of Carrageenan as a Gelling Agent \\ Hamka $^{1^{*}}$, Nurita $^{1}$, Marwati $^{2}$, Eva Nurmarini ${ }^{1}$ \\ ${ }^{1}$ Jurusan Teknologi Pertanian, Politeknik Pertanian Negeri Samarinda, Indonesia. \\ ${ }^{2}$ Jurusan Teknologi Hasil Pertanian, Fakultas Pertanian Universitas Mulawarman, Indonesia. \\ Corresponding Author: hamka@politanisamarinda.ac.id
}

\begin{abstract}
ABSTRAK
Buah naga merupakan komoditi pertanian Indonesia yang mengandung banyak nutrisi penting bagi tubuh. Buah naga diketahui mampu menurunkan kolestrol serta menyeimbangkan kadar gula darah dalam tubuh. Sayangnya, buah naga mudah mengalami kerusakan. Selain itu, buah naga juga sering mengalami penurunan harga terutama ketika jumlah panen melimpah. Oleh karena itu, diperlukan upaya untuk mengolah buah naga menjadi produk olahan yang bernilai ekonomi tinggi, salah satu contohnya adalah dengan mengolah menjadi permen jelly. Pada penelitian ini dilakukan pembuatan permen jelly berbahan buah naga dengan menggunakan karagenan sebagai bahan pembuat gel. Penelitian ini berutujuan untuk mengetahui sifat kimia dan tingkat kesukaan panelis terhadap permen jelly buah naga dengan penambahan karagenan pada konsentrasi yang berbeda. Metode penelitian ini menggunakan Rancangan Acak Lengkap dengan 1 faktor perlakuan yaitu perbedaan konsentrasi karagenan (3\%, 5\% dan 7\%). Hasil penelitian menunjukkan bahwa kadar air permen jelly buah naga pada semua tingkat konsentrasi karagenan telah memenuhi SNI-3547-2-2008 dengan nilai rata-rata berkisar antara 4,78-6,61\% (kadar air maksimal menurut SNI adalah 20\%). Hasil analisa kadar abu permen jelly buah naga menunjukkan bahwa hanya perlakuan karagenan 3\% yang memenuhi kriteria SNI dengan nilai kadar abu sebesar 2,91\% (maksimal menurut SNI $3 \%$ ). Pada uji organoleptik didapatkan bahwa perlakuan terbaik yang disukai panelis terdapat pada perlakuan dengan penambahan karagenan $3 \%$ dengan nilai rata-rata aroma 3,33 (agak suka), warna 3,60 (suka), rasa 3,53 (suka) dan tekstur 3,45 (agak suka).
\end{abstract}

Kata kunci: buah naga, permen jelly, sifat kimia, uji organoleptic

\begin{abstract}
Dragon fruit is an Indonesian agricultural commodity that contains many essential nutrients for the body. Dragon fruit is known to reduce cholesterol and balance blood sugar levels in the body. Unfortunately, dragon fruit is easily damaged. In addition, dragon fruit also often experiences price declines especially when the amount of harvest is abundant. Therefore, efforts are needed to process dragon fruit into processed products of high economic value; one example is to process them into jelly candies. In this research, jelly candies were made from dragon fruit by using carageenan as gelling agent. This study aims to determine the chemical properties and the level of preference of panelists on dragon fruit jelly candy with the addition of carrageenan at different concentrations. The experimental design used in this study is a completely randomized design with 1 treatment factor, namely the difference in carrageenan concentration (3\%, 5\%, and $7 \%$ ). The results showed that the water content of dragon fruit jelly candy at all levels of carrageenan concentration had fulfilled SNI-3547-2-2008 with an average value ranging from 4.78 to $6.61 \%$ (maximum water content according to SNI was 20\%). And the ash content required by SNI-3547-2-2008 for jelly candy is $3 \%$ according to the treatment of adding $3 \%$ carrageenan with a value of $2.91 \%$. The organoleptic test showed that the best treatment that panelists prefer is the treatment with the addition of $3 \%$ carrageenan with an average value of aroma 3.33 (somewhat like), color 3.60 (like), taste 3.53 (like) and texture 3.45 (somewhat like).
\end{abstract}

Keywords: dragon fruit, jelly candy, chemical properties, organoleptic test

\section{PENDAHULUAN}

Berbagai macam buah-buahan yang terdapat di Indonesia salah satunya ialah buah naga. Buah ini memiliki berbagai macam jenis yaitu buah naga merah, buah naga putih dan buah naga kuning. Akan tetapi yang banyak ditanam dan ditemukan di Indonesia adalah buah naga merah. Buah 
naga termasuk komoditi baru di Indonesia dengan bentuk yang unik, warna memikat dengan biji kecil berwarna hitam yang sangat lembut dan lunak. Buah naga ini mengandung vitamin $\mathrm{C}$, beta karoten, kalsium dan karbohidrat. Buah naga ini juga mampu menurunkan kolestrol, menyeimbangkan kadar gula darah dan kaya akan serat (Rahayu, 2014).

Permen jelly merupakan permen yang terbuat dari campuran sari buah-buahan, bahan pembentuk gel atau dengan penambahan essens untuk menghasilkan berbagai macam rasa, dengan bentuk fisik jernih transparan serta mempunyai tekstur kenyal (Malik, 2010). Salah satu faktor yang mempengaruhi mutu permen jelly adalah adanya bahan pembentuk gel. Gel yang kuat dan tekstur yang kenyal pada permen jelly dapat dihasilkan dengan adanya penambahan bahan yang mengandung pembentuk gel. Bahan pengental yang biasa digunakan pada permen jelly adalah karagenan, pektin, gelatin, dekstri dan karbon metil selulosa (Isnanda, dkk., 2016).

Buah naga merah pada umumnya mengalami kerusakan jika tidak diolah lebih lanjut dan ketika buah naga melimpah di pasar terkadang mengalami penurunan harga. Salah satu kerusakan yang dialami buah naga ialah pembusukan dan untuk meningkatkan nilai ekonomi pada buah naga salah satunya dapat diolah menjadi produk yaitu permen jelly buah naga. Pada penelitian pembuatan permen jelly buah naga menggunakan bahan karagenan sebagai bahan pembuat jelly.

\section{METODE PENELITIAN}

\section{A. Alat dan Bahan Penelitian}

Penelitian ini dilakukan di Laboratorium Pengolahan Program Studi Teknologi Hasil Perkebunan dan Laboratorium Kimia Analitik Jurusan Teknologi Pertanian Politeknik Pertanian Negeri Samarinda. Alat yang digunakan dalam pembuatan Permen Jelly Buah Naga adalah cabinet dryer, loyang, timbangan analitik, pisau, saringan, penggaris, baskom, sendok, panci, kompor, plastik roll warpping, alumunium foil, oven, tanur, cawan, gegep, desikator. Bahan yang digunakan dalam pembuatan Permen Jelly
Buah Naga adalah sari buah naga merah, air, karagenan, gula dan asam sitrat.

B. Prosedur Pembuatan Permen Jelly Buah Naga

Buah naga dibelah dan dipotong kemudian dibuang bagian kulitnya. Daging buah dihancurkan dan dicacah diatas saringan untuk memisahkan biji dan sari buah. $500 \mathrm{ml}$ Sari buah kemudian dipanaskan lalu ditambahkan air $400 \mathrm{ml}$, gula $150 \mathrm{ml}$, dan asam sitrat 0,5 gram serta karagenan sesuai perlakuan $(3 \%, 5 \%$ dan $7 \%$ ). Dilakukan pengadukan sampai homogen dalam keadaan dimasak dan sampai mendidih. Selanjutnya dituangkan kedalam loyang untuk didinginkan pada suhu ruang kemudian ditutup menggunakan roll warpping, lalu didiamkan selama 3 jam. Permen Jelly yang terbentuk dicetak menggunakan cetakan dengan ketebalan 1 $\mathrm{cm}$. Permen jelly tersebut kemudian dikeringkan dalam cabinet dryer selama 16 jam pada suhu $80^{\circ} \mathrm{C}$. Setelah dikeringkan permen jelly siap untuk dilakukan pengujian lanjutan.

C. Rancangan Percobaan

Penelitian ini menggunakan metode rancangan acak lengkap (RAL) dengan menggunakan 1 faktor yaitu dengan konsentrasi penambahan karagenan berbeda. Dalam penelitian ini ada 3 perlakuan yaitu konsentrasi karagenan 3\%, konsentrasi karagenan 5\%, konsentrasi karagenan $7 \%$ yang diulang sebanyak 3 kali ulangan. Adapun parameter yang akan diamati pada penelitian ini adalah sifat kimia (kadar air dan kadar abu) menggunakan metode sudarmadji (Sudarmadji, 1997) dan uji organoleptik meliputi warna, rasa, aroma dan tekstur menggunakan metode Setianingsih (Setianingsih, 2010).

D. Analisa Data

Data yang diperoleh dianalisis menggunakan sidik ragam (ANOVA). Data yang menunjukkan perbedaan nyata pada perlakuan, maka akan dilanjutkan dengan Uji Tukey Test pada taraf $\alpha 5 \%$.

\section{HASIL DAN PEMBAHASAN}

\section{A. Sifat Kimia}

Hasil sifat kimia (kadar air dan kadar abu) dapat dilihat pada Gambar 1. 


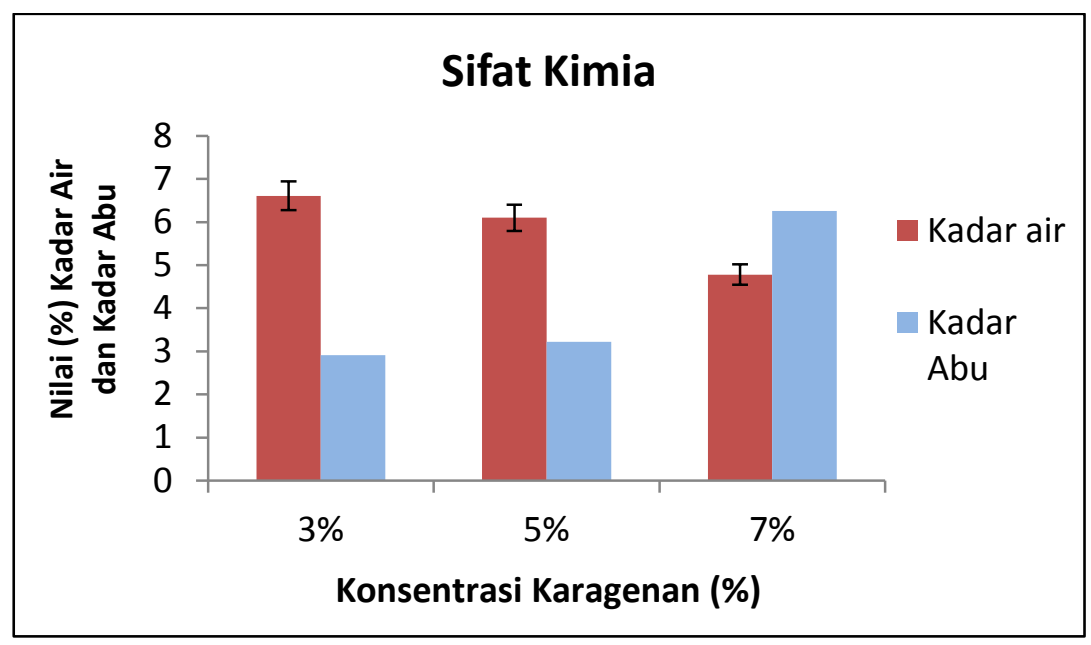

Gambar 1. Hasil Analisa sifat kimia (kadar abu dan kadar air) dari penambahan konsentrasi karagenan dalam pembuatan permen jelly buah naga

Tabel 1. Analisis sidik ragam kadar air permen jelly buah naga dengan penambahan karagenan

\begin{tabular}{ccccccc}
\hline $\begin{array}{c}\text { Sumber } \\
\text { Keragaman }\end{array}$ & $\begin{array}{c}\text { Derajat } \\
\text { Bebas }\end{array}$ & $\begin{array}{c}\text { Jumlah } \\
\text { Kuadrat }\end{array}$ & $\begin{array}{c}\text { Kuadrat } \\
\text { Tengah }\end{array}$ & F. Hit & \multicolumn{2}{c}{ F Tabel } \\
\hline Perlakuan & 2 & 5,33 & 2,66 & $3,44^{\text {th }}$ & 5,14 & 10,92 \\
Galat & 6 & 4,63 & 0,77 & & & \\
\hline Total & 8 & 9,96 & & & & \\
\hline
\end{tabular}

Keterangan: $\mathrm{tn}=$ tidak berbeda nyata

Tabel 2. Analisis sidik ragam kadar abu permen jelly buah naga dengan penambahan karagenan

\begin{tabular}{ccccccc}
\hline \multirow{2}{*}{$\begin{array}{c}\text { Sumber } \\
\text { Keragaman }\end{array}$} & $\begin{array}{c}\text { Derajat } \\
\text { Bebas }\end{array}$ & $\begin{array}{c}\text { Jumlah } \\
\text { Kuadrat }\end{array}$ & $\begin{array}{c}\text { Kuadrat } \\
\text { Tengah }\end{array}$ & F. Hit & \multicolumn{2}{c}{ F Tabel } \\
\hline Perlakuan & 2 & 20,58 & 10,29 & $7,76^{*}$ & 5,14 & 10,92 \\
Galat & 6 & 7,95 & 1,32 & & & \\
\hline Total & 8 & 28,53 & & & & \\
\hline
\end{tabular}

Keterangan: *Fhitung $>\mathrm{F}$ tabel $5 \%<$ Ftabel $1 \%$, berpengaruh nyata

Nilai hasil analisa kadar air pada permen jelly buah naga dengan penambahan karagenan pada (gambar 1) menunjukkan bahwa kadar air terendah terdapat pada perlakuan kosentrasi karagenan $7 \%$ yaitu dengan nilai rata-rata $4,78 \%$. Semakin tinggi konsentrasi karagenan yang digunakan pada suatu bahan, maka kadar air yang terkandung pada bahan tersebut semakin rendah. Hal ini diduga karena karagenan berfungsi sebagai pengental yang memiliki kemampuan untuk mengikat air (Fajarini dkk.,
2018). Sedangkan kadar air tertinggi terdapat pada perlakuan karagenan $3 \%$ dengan nilai rata-rata $6,61 \%$. hal ini diduga konsentrasi karagenan yang digunakan lebih rendah dibanding dengan perlakuan konsentrasi $5 \%$ dan $7 \%$ dari ppenambahan jumlah karagenan. Berdasarkan standar mutu SNI 3547-2-2008 untuk permen jelly yaitu maksimal $20 \%$. Sementara untuk hasil analisa sidik ragam menunjukkan bahwa kadar air permen jelly buah naga dengan penambahan karagenan yang dihasilkan 
tidak berbeda nyata. Hal ini disebabkan karena setiap perlakuan pada proses pengovenan yang diberikan untuk suhu dan lama waktunya sama.

Nilai hasil analisa kadar abu pada permen jelly buah naga dengan penambahan karagenan pada (gambar 1) menunjukkan bahwa kadar abu terendah pada perlakuan $3 \%$ dengan nilai $2,91 \%$ dan nilai tertinggi terdapat pada perlakuan konsentrasi karagenan $7 \%$ yaitu dengan nilai $6,26 \%$. Hal ini disebabkan konsentrasi karagenan yang ditambahkan semakin banyak maka kadar abu permen jelly semakin tinggi. Menurut Fajarini dkk., (2018) hal ini dipengaruhi oleh kandungan mineral yang terdapat pada kappa karagenan yang digunakan. Menurut Sukri (2006), semakin tinggi konsentrasi karagenan yang ditambahkan maka kadar abu permen jelly semakin meningkat karena karagenan di buat dari rumput laut yang termasuk dalam bahan pangan yang mengandung mineral yang cukup tinggi. Berdasarkan hasil analisa sidik ragam menunjukkan bahwa kadar abu permen jelly buah naga dengan penambahan karagenan yang dihasilkan menunjukkan berpengaruh nyata. Hal ini disebabkan pada penambahan karagenan yang digunakan berbeda pada setiap perlakuan. Berdasarkan SNI 3547-21008 untuk permen jelly untuk kadar abu maksimal adalah $3 \%$. Ini sesuai dengan perlakuan penambahan karagenan $3 \%$ dengan nilai $2.91 \%$.

\section{B. Uji Organoleptik}

Hasil uji organoleptik meliputi aroma, warna, rasa, dan tekstur dapat dilihat pada gambar 2 dibawah ini.

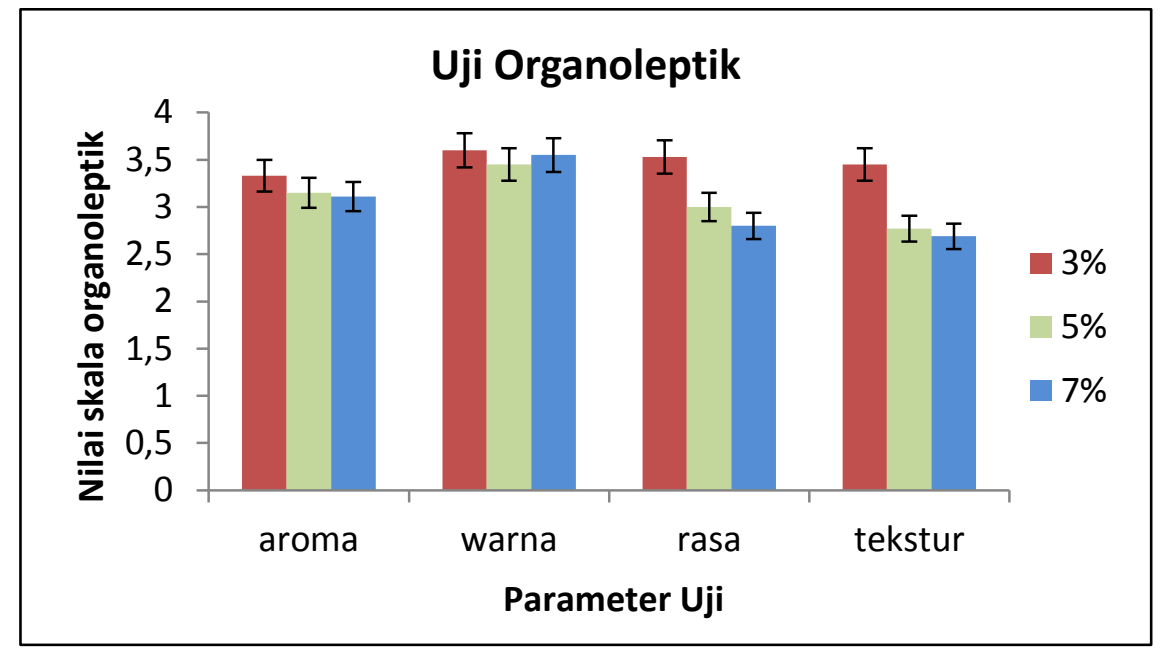

Gambar 2. Hasil uji organoleptik dari penambahan konsentrasi karagen yang berbeda pada pembuatan permen jelly buah naga

Tabel 3. Uji Organoleptic berdasarkan hasil sidik ragam dari penambahan konsentrasi karagen yang berbeda pada pembuatan permen jelly buah naga

\begin{tabular}{lccc}
\hline \multirow{2}{*}{$\begin{array}{c}\text { Uji } \\
\text { Organoleptik }\end{array}$} & F Hitung & \multicolumn{2}{c}{ F Tabel } \\
\cline { 3 - 4 } & & $5 \%$ & $1 \%$ \\
\hline Aroma & $9,14^{*}$ & 5,14 & 10,92 \\
Warna & $0,47^{\text {tn }}$ & 5,14 & 10,92 \\
Rasa & $26,64^{* *}$ & 5,14 & 10,92 \\
Tekstur & $29,72^{* *}$ & 5,14 & 10,92 \\
\hline
\end{tabular}

Keterangan : *) Fhitung $>\mathrm{F}$ tabel $5 \%<$ Ftabel 1\%, berpengaruh nyata

$\left.{ }^{\mathrm{tn}}\right)$ tidak berbeda nyata

${ }^{* *}$ ) Fhitung $>$ Ftabel $5 \%>$ Ftabel $1 \%$, berpengaruh sangat nyata 
Hasil gambar 2, diperoleh nilai ratarata uji organoleptik atau tingkat kesukaan panelis terhadap aroma, warna, rasa, dan tektur. Menurut Setyaningsih dkk., (2010) parameter uji organoleptik seperti aroma, warna, rasa, dan tektur merupakan cara untuk mengetahui ciri khas dari produk dan juga dapat mempengaruhi penilaian konsumen/panelis. pada permen jelly buah naga dengan penambahan karagenan menunjukkan bahwa dari semua perlakuan yang paling disukai oleh panelis adalah perlakuan penambahan karagenan sebanyak $3 \%$ dengan rata-rata nilai 3,33 (agak suka), kemudian penambahan karagenan sebanyak $5 \%$ ) dengan rata-rata nilai 3,15 (agak suka). Sedangkan nilai tingkat kesukaan aroma yang terendah adalah pada penambahan karagenan sebanyak $7 \%$ dengan rata-rata nilai 3,11 (agak suka). Berdasarkan table 3, hasil analisa sidik ragam menunjukkan pada aroma permen jelly buah naga dengan penambahan karagenan berpengaruh nyata. Hal ini diduga sesuai dengan pernyataan Eveline dkk.,(2009) yang menyatakan bahwa aroma asing dari jelly berasal dari karagenan yang memiliki karakteristik berbau amis.

Menurut Holisneti (2009), penilaian organoleptik untuk warna merupakan salah satu faktor yang mempengaruhi penerimaan konsumen terhadap produk tersebut. Nilai rata-rata uji organoleptik terhadap warna pada permen jelly buah naga dengan penambahan karagenan menunjukkan bahwa dari semua perlakuan yang paling disukai oleh panelis adalah perlakuan penambahan karagenan sebanyak $3 \%$ dengan rata-rata nilai 3,60 (suka), kemudian penambahan karagenan sebanyak $7 \%$ dengan rata-rata nilai 3,55 (suka). Sedangkan nilai tingkat kesukaan warna yang terendah adalah pada penambahan karagenan sebanyak $5 \%$ dengan rata-rata nilai 3,45 (agak suka). Berdasarkan (tabel 3) hasil analisa sidik ragam warna menunjukkan bahwa penambahan karagenan tidak berbeda nyata pada permen jelly buah naga yang dihasilkan pada setiap perlakuan. Hal ini diduga disebabkan oleh karagenan tidak memiliki pigmen warna, karagenan sebelum dilarutkan berwarna putih kecoklatan dan setelah dilarutkan dengan air panas sehingga karagenan akan larut dan membentuk gel transparan (Zhaki dkk., 2018).
Berdasarkan (gambar 2) diperoleh nilai rata-rata uji organoleptik terhadap rasa pada permen jelly buah naga dengan penambahan karagenan menunjukkan bahwa dari semua perlakuan yang paling disukai oleh panelis adalah perlakuan penambahan karagenan sebanyak 3\% dengan rata-rata nilai 3,53 (suka), kemudian penambahan karagenan sebanyak $5 \%$ dengan rata-rata nilai 3,00 (agak suka). Sedangkan nilai tingkat kesukaan warna yang terendah adalah pada penambahan karagenan sebanyak $7 \%$ dengan rata-rata nilai 2.80 (agak suka). Hasil (tabel 3) analisis sidik ragam memperlihatkan adanya perbedaan rasa dari penambahan karagenan. Pada tabel analisis sidik ragam diatas diketahui bahwa beberapa perlakuan berpengaruh sangat nyata. Hal ini diduga bahwa respon panelis terhadap rasa permen jelly sangat beragam. Hal ini disebabkan oleh karena karakteristik karagenan yang bersifat tawar atau tidak memiliki rasa dan hanya sebagai pembentuk gel (Zhaki dkk., 2018).

Berdasarkan (gambar 2) diperoleh nilai rata-rata uji organoleptik terhadap tekstur pada permen jelly buah naga dengan penambahan karagenan menunjukkan bahwa dari semua perlakuan yang paling disukai oleh panelis adalah perlakuan penambahan karagenan sebanyak $3 \%$ dengan rata-rata nilai 3,45 (agak suka), kemudian penambahan karagenan sebanyak 5\% dengan rata-rata nilai 2.77 (agak suka). Sedangkan nilai tingkat kesukaan warna yang terendah adalah pada penambahan karagenan sebanyak $7 \%$ dengan rata-rata nilai 2,69 (agak suka). Hasil (table 3) analisis sidik ragam memperlihatkan adanya perbedaan tekstur dari penambahan karagenan. Pada tabel analisis sidik ragam diatas diketahui bahwa beberapa perlakuan berpengaruh sangat nyata. Hal ini diduga karagenan merupakan hidrokoloid yang berfungsi membentuk seperti gel. Pembentukan gel adalah penggabungan atau pengikat silang rantai-rantai polimer sehingga terbentuk jaringan tiga dimensi. Jaringan ini mengikat air didalamnya dan membentuk struktur yang kuat (Zhaki dkk., 2018). Sehingga diduga semakin tinggi konsentrasi penambahan karagenan yang digunakan maka semakin kuat pula mengikat air sehingga tekstur semakin kuat. 


\section{KESIMPULAN}

Berdasarkan hasil penelitian pembuatan permen jelly buah naga (hylocereus polyrhizus) dengan penambahan karagenan didapatkan hasil untuk sifat kimia pada uji kadar air untuk semua perlakuan dengan nilai rata-rata berkisar antara 4,78$6,61 \%$ telah memenuhi SNI 3547-2-1008 untuk permen jelly yang maksimal $20 \%$ untuk kadar air. Pada uji kadar abu perlakuan 3\% penambahan karagenan dengan nilai 2,91\% sesuai dengan SNI 3547-2-1008 untuk permen jelly yang maksimal $3 \%$ untuk kadar abu. Sementara untuk uji organoleptik yang dihasilkan terhadap aroma, warna, rasa dan tekstur pada permen jelly buah naga dengan penambahan karagenan yakni perlakuan terbaik yang disukai panelis pada penambahan karagenan 3\% untuk aroma 3,33 (agak suka), warna 3,60 (suka), rasa 3,53 (suka) dan tekstur 3,45 (agak suka).

\section{DAFTAR PUSTAKA}

Badan Standar Nasional Indonesia. 2008. SNI 3547-02-2008 Kembang Gula Lunak. Departemen Perindustrian. Jakarta.

Eveline, Santoso, J., dan Widjaya, I. 2009. Kajian Konsentrasi dan Rasio Gelatin dari Kulit Ikan Patin dan Kappa Karagenan pada Pembuatan Jeli. Jurnal Penelitian Jurusan Teknologi Pangan Fakultas Teknologi Industri Universitas Pelita Harapan.

Fajarini, R., Ekawati, G., dan Ina, P. 2018. Pengaruh Penambahan Karagenan Terhadap Karakteristik Permen Jelly Kulit Anggur Hitam (Vitis vinifera). Program Studi Ilmu dan Teknologi Pangan Fakultas Teknologi Pertanian. Unud.

Holinesti, Rahmi. 2009. Studi Pemanfaatan Pigmen Brazilein Kayu Secang (Caesalpinia sappan L.) Sebagai Pewarna Alami Serta Stabilitasnya pada Model Pangan. Jurnal Pendidikan dan Keluarga UNP. Vol. I, No. 2, Page 11-21.

Isnanda, D., Novita, M., dan Rohaya, S. 2016. Pengaruh Konsentrasi Pektin dan Karagenan terhadap Permen jelly Nanas (Ananas comosus L. Merr).
Jurnal Penelitian Fakultas Pertanian Universitas Syiah Kuala.

Malik. 2010. Pembuatan Permen Jelly. Universitas Sumatra Utara.

Rahayu, S. 2014. Budidaya Buah Naga Cepat Panen. Jakarta: Infra Hijau.

Setyaningsih, D., A. Apriyantono, dan M. P. Sari. 2010. Analisis Sensori untuk Industri Pangan dan Agro. Institut Pertanian Bogor Press. Bogor

Sudarmadji, M., Haryono B., dan Suhardi. 1997. Prosedur Analisa untuk Bahan Makanan dan Pertanian. Yogyakarta: Liberty.

Sukri, N. 2006. Karakteristik Alkali Tread Cottonii (ATC) dan Karagenan dari Rumput Laut Euchema cottonii Pada Umur Panen yang Berbeda. Program Studi Teknologi Hasil Perikanan Fakultas Perikanan dan IImu Kelautan. Insititut Pertanian Bogor.

Zhaki, M., Harun, N., dan Hamzah, F. 2018. Penambahan Berbagai Konsentrasi Karagenan terhadap Karakteristik Fruit Leather Pepaya. Jurnal Penelitian Universitas Riau. 